2. An industrialist's concept of government's part in forestry. B. Avery, K.V.P. Company.

3. A government forester's concept of industry's role in forestry. (To be selected).

Discussion.

11:00-12:00 Conclusion and Summation. Major General H. Kennedy, Consulting Engineer.

1:30- 4:00 Business Session.

The next issue of the Chronicle will contain such additional information as may be available at that time.

Anyone wishing further information with reference to the meeting or other aspects of their stay in Winnipeg should contact A. J. Reeve, Chairman Publicity and Information Committee, Game and Fisheries Branch, Department of Mines and Natural Resources, 469 Broadway Avenue, Winnipeg, Manitoba.

\title{
AWARDS
}

\section{SCHLICH MEMORIAL AWARD}

Kenneth George Boyd of the senior class of the Faculty of Forestry at U.B.C. has recently been announced the winner of the Schlich Memorial Fund Award. The Faculty decided to make the award on the best third and fourth year essay written by forestry and forest engineering students during the current year. Ken Boyd received a grade of $86 \%$ on his essay entitled "B.C. Forest Service, Forest Surveys Procedure". His class averages for the last year and the past four years were all first class; he would have lead his class at graduation except that he was unable to complete field camp requirements previously and will not graduate until this fall.

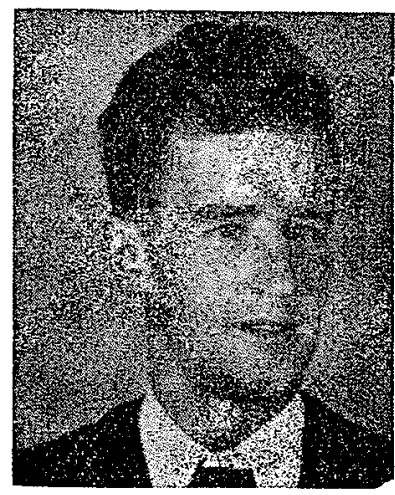

Boyd was born in Ashcroft, British Columbia, in 1929 and spent most of his life in the Kamloops and Interior areas. He has worked on forest surveys with the B.C. Forest Service every summer while attending school 
and has been rated as an oustanding man by the Forest Service each year. He will take up employment with the Chemainus Logging Division of MacMillan and Bloedel Ltd., on Vancouver Island.

Ken Boyd has been active in the Forest Club as chairman of the Education Committee which arranges for talks by students at the High Schools. In this regard his committee revised and expanded its publication "Opportunities in the Forest and Forest Industries of B.C.", a great deal of which he personally revised and rewrote. He was also responsible for the chapter on Sampling Procedures in the Forestry Handbook for British Columbia, produced as a co-operative effort by the Forestry Club at U.B.C. and currently at the printers.

\section{Gold Medal Award}

James McWilliams was recently announced winner of the Gold Medal Awarded by the B.C. Sections of the Canadian Institute of Forestry for the

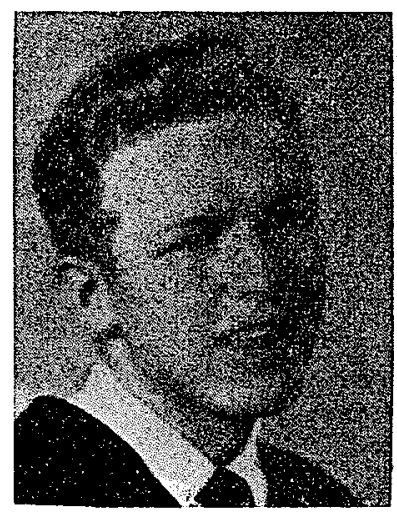

graduating forester or forest engineer who has made the best all around record for the whole four years. Jim is also winner of the Rhodes Scholarship from U.B.C. this year, and the first forestry graduate in Canada ever to win a Rhodes Scholarship. He was president of the Forest Club where he did an excellent job, as well as playing rugger for the University. He will be at St. John's College, Oxford, next fall. Jim is the son of Harold G. McWilliams who is forester-in-charge of reforestation with the B.C. Forest Service and a member of the C.I.F.

\section{C.I.F.-S.A.F. Annual Meeting Papers Journal of Forestry}

The following list indicates the Joint C.I.F.S.A.F. Montreal meeting papers which were published in the April and May issues of the Journal of Forestry, together with those appearing in the June issue.

April

Forest Grazing in the United States, by Walt L. Dutton May

A Survey of Forest Genetics Research, by Jonathan W. Wright Public Relations and the Forester, by Fred L. Palmer 
Ecology and Silviculture of the Englemann Spruce-Alpin Fir Type, by Russell K. LeBarron and George M. Jemison

June

Trends in Forestry Education in North America, by Myron Krueger

Factors Affecting Successful job Performance by the Young Forester, by W. F. McCulloch

Ecology and Silviculture of the Spruce-Fir Forests of Eastern Nortb America, by Marinus Westveld

The Role of Humanities and Other Liberal Courses in the Professional Forestry Curriculum, by John W. Barrett

Modification of Forest Practices in the Lake States for Wildlife Habitat Betierment, by Ernest Swift.

\section{Central International Forest Insect and Disease Conference ${ }^{1}$}

On January 6 and 7, 1953 forest entomologists and forest pathologists of Minnesota, Michigan, Wisconsin, Ontario, Manitoba and Saskatchewan met at the University of Minnesota, St. Paul, Minnesota to participate in a pioneer meeting of the Central International Forest Insect and Disease Conference. The morning of January 6 was devoted to organizational matters, and the remainder of the meeting period was spent in outlining problems and work in progress at the forest insect and disease research centers throughout the area from which representation was obtained.

Participating in the initial meeting were Dr. J. A. Beal, Chief, Division of Forest Insect Investigations, USDA; Dr. J. R. Hansbrough, Senior Pathologist in Charge, Division of Forest Pathology, USDA (New Haven Laboratory); Dr. M. L. Prebble, Chief, Division of Forest Biology, Department of Agriculture, Ottawa; and Dr. J. E. Bier, Associate Chief, Division of Forest Biology. The following laboratories, Universities and State agencies concerned with forest insect and disease problems were represented:

Departments of Conservation (Michigan, Wisconsin, Minnesota)

Universities (Minnesota, Michigan, Michigan State College, Wisconsin, Toronto)

Offices of State Entomologist (Minnesota, Wisconsin)

Canadian Department of Agriculture, Laboratories of Forest Biology (Saskatoon, Indianhead, Winnipeg, Sault Ste. Marie, Toronto)

U.S. Department of Agriculture (Forest Insect Laboratory Region 9, Division of Forest Pathology)

It was unanimously agreed that future meetings should continue to

1 James W. Butcher, Forest Entomology, University Farm, St. Paul 1, Minnesota. 